\title{
Migration communications of municipal units of Altai krai
}

\section{DOI: $10.31551 / 2410-2725-2018-4-4-576-590$}

\section{Tarasova Elena Vladimirovna}

Candidate of History, Chief of control section of the secretariat of the Governor of Altai Krai. Russian Federation, 656035, Barnaul, Lenin Ave., 59. E-mail: forschung2005@gmail.com

\begin{abstract}
Multidirectional dynamics of demographic development of the cities and areas of Altai Krai is one of the leading factors of deepening of unevenness of their development. Non-uniform results of migration processes have municipal units of Altai Krai that is caused by a set of factors: geographical location, structure of the population, development of infrastructure, current social and economic situation and related dynamics of individual requirements.

Subject of the analysis are migration communications of municipal units of Altai Krai. The Istochnikovy base of a research was made by data of Management of Federal State Statistics Service in Altai Krai and Altai Republic on population shift across territories of arrival and leaving.

Assessment of character and stability of communications between intraregional migration and indicators of social and economic development of municipal units has the big scientific and practical importance. Municipal units of Altai Krai are substantially differentiated on a share of intra regional migration in structure of arrival and leaving. Intermunicipal migration significantly influences the number and the age and sex structure of the population of territories of Altai Krai, aggravating their economical and demographic inequality. The analysis of intensity of intermunicipal migration communications showed that mainly "neighbour's" migrations are characteristic of all territories of Altai Krai.

Keywords: migration; municipalities; Altai Region.
\end{abstract}

\section{Алтай өлкесінің муниципиалдық құрылымдарының көші-қон байланыстары}

\section{Тарасова Елена Владимировна}

тарих ғылымдарының кандидаты, Алтай өлкесінің Губернаторы секретариатының бақылау бөлімінің бастығы. Ресей Федерациясы, 656035, Барнаул қ, Ленин даңғылы, 59. E-mail: forschung2005@gmail.com

Аңдатпа. Алтай өлкесінің қалалары мен аудандарының демографиялық даму динамикасының әртүрлі бағыттылығы, олардың әркелкі болып дамуын тереңдететін фракторлардың бірі болып табылады. Алтай өлкесінің муниципалды құрылымдары көші-қон үрдістерінің әртүрлі нәтижелеріне ие, ол көптеген фракторлармен, яғни географриялық орналасуы, халықтың құрамы, инфрақұрылымының дамуы, ағымды әлеуметтік-экономикалық жағдай және одан туындайтын жеке тұтынушылықтар динамикасымен байланысты.

Талдау пәні Алтай өлкесінің муниципалды құрылымдарының көші-қон байланыстары болып табылады.

Зерттеудің деректік негізін Алтай Республикасы және Алтай өлкесі бойынша мемлекеттік статистика қызметінің Федералдық Басқармасының халықтың көші-қоны туралы, яғни келу және шығып кету территориялары бойынша мәліметтер құрайды.

Ішкі аймақтық көші-қон және муниципалдық құрылымдардың әлеуметтік-экономикалық дамуының көрсеткіштері арасындағы байланыстардың тұрақтылығын және сипатын бағалаудың ғылыми және тәжірибелік маңызы зор. Алтай өлкесінің муниципалдық құрылымдары келу және шығып кету құрылымында ішкі өлкелік көші-қон үлесі бойынша елеулі дәрежеде диффреренциалды болып табылады. Муниципалдыаралық көші-қон Алтай өлкесі территориясы халқының санына және жас-жыныс құрамына маңызды әсер етеді, олардың экономикодемографиялық теңсіздігін шиеленістіреді. Муниципалдыаралық көші-қон байланыстарының интенсивтігін талдау Алтай өлкесінің барлық территориясы үшін «көршілік» көші-қон басымды сипатта екендінгін көрсетті.

Түйінді сөздер: көші-қон; муниципалдық құрылымдар; Алтай өлкесі. 


\section{Миграционные связи муниципальных образований Алтайского края}

\section{Тарасова Елена Владимировна}

кандидат исторических наук, начальник контрольного отдела секретариата Губернатора Алтайского края. Российская Федерация, 656035, г. Барнаул, пр. Ленина, 59. E-mail: forschung2005@gmail.com

Аннотация. Разнонаправленная динамика демографического развития городов и районов Алтайского края является одним из ведущих факторов углубления неравномерности их развития. Муниципальные образования Алтайского края имеют неоднородные результаты миграционных процессов, что обусловлено множеством фракторов: географическим положением, составом населения, развитостью инфраструктуры, текущей социально-экономической ситуацией и связанной с ней динамикой индивидуальных потребностей.

Предметом анализа являются миграционные связи муниципальных образований Алтайского края. Источниковую базу исследования составили данные Управления Федеральной службы государственной статистики по Алтайскому краю и Республике Алтай о миграции населения по территориям прибытия и выбытия.

Оценка характера и устойчивости связей между внутрирегиональной миграцией $и$ показателями социально-экономического развития муниципальных образований имеет большую научную и практическую значимость. Муниципальные образования Алтайского края в значительной степени дифференцируются по доле внутрикраевой миграции в структуре прибытия и выбытия. Межмуниципальная миграция существенно влияет на численность и возрастно-половой состав населения территорий Алтайского края, обостряя их экономикодемографическое неравенство. Анализ интенсивности межмуниципальных миграционных связей показал, что для всех территорий Алтайского края характерны преимущественно «соседские» миграции.

Ключевые слова: миграция; муниципальные образования; Алтайский край.

\section{ӘОЖ/ УДКЗ14.728}

\section{Миграционные связи муниципальных образований Алтайского края}

\section{E.B. Тарасова}

Введение. Внутрирегиональная миграция, доминирующая в структуре миграционного оборота большинства субъектов Российской Федерации, редко становилась предметом научных исследований. Долгое время приоритет отдавался изучению различных видов международных миграций вынужденных, трудовых, учебных. Внутренняя миграция населения России оставалась в тени международной проблематики и лишь в последнее время стала занимать заслуженное место. В отечественной науке сложилась ситуация, когда большинство научных исследований и предлагаемых моделей управленческих решений ориентированы на внешние по отношению к субъекту РФ миграции - международные и межрегиональные.

В современных условиях, характеризующихся сокращением возможностей привлечения внешних ресурсов и углублением территориальной асимметрии в регионах Российской Федерации, возросла актуальность научного анализа причинно-факторных механизмов социально-экономической диффреренциации муниципальных образований. Смещение центра тяжести реализации социально-экономической политики на муниципальный уровень обнажило недостаточную теоретическую проработанность вопросов анализа внутрирегиональной миграции, отсутствие адекватных методик оценки ее направлений, масштабов и многообразия последствий. Актуальность проблемы обусловлена необходимостью совершенствования научно- 
методического аппарата оценки и прогнозирования социально-экономического развития муниципальных образований, корректного учета тенденций демографического развития малых территорий при планировании развития сети объектов социальной инфраструктуры и инвестиционных проектов.

Предметом анализа является миграционный обмен между муниципальными образованиями Алтайского края. В рамках данного исследования рассматривались общие характеристики миграционной ситуации в регионе, специфика внутрикраевой миграции, направления и интенсивность миграционных связей городских округов и муниципальных районов региона.

Источниковую базу исследования составили данные Управления Федеральной службы государственной статистики по Алтайскому краю и Республике Алтай. Хронологические рамки анализа основных характеристик миграционных процессов в Алтайском крае в данной статье ограничены преимущественно 2011 - 2017 гг., поскольку этот период отличается методическим единством принципов учета миграции.

Масштабы внутренней миграции в России, как и в большинстве других стран, существенно превосходят масштабы миграции международной. Однако миграция населения муниципальных образований далеко не всегда находилась в фокусе исследований.

Отечественные ученые стали уделять значительное внимание региональным особенностям миграции с 1960-х гг. Однако, несмотря на заметный «региональный уклон» миграционных исследований, объектом изучения по-прежнему оставалось, преимущественно, население крупных административно-территориальных единиц: городское/сельское население страны в целом, экономико-географических районов (которые в современных условиях назвали бы макрорегионами) или союзных республик. Термин «межрайонные миграции» широко использовался, но трактовался как миграционный обмен между экономическими районами или республиками СССР. Непосредственно территории уровня областей и районов не становились самостоятельным объектом анализа.

Тем не менее, в ряде научных работ эмпирической базой послужили показатели миграции регионов СССР и входящих в их состав городов. Примером могут служить работы, посвященные миграции населения Западной Сибири и Дальнего Востока (Зайончковская, 1972; Переведенцев, 1964; Переведенцев, 1965; Рыбаковский, 1969). Изложенные в них данные (статистические и полученные опросными методами) могут быть источником для реконструкции истории миграции населения отдельных субъектов Российской Федерации, в том числе Алтайского края. Существенным научным вкладом Л.Л. Рыбаковского является предложенный им коэффиццент интенсивности миграционных связей (КИМС), позволяющий сопоставить миграционные связи между территориями.

После распада СССР произошла резкая актуализация вопросов внешней (международной) миграции, вопросы внутренней территориальной мобильности на некоторое время отошли на второй план. Фактором, в значительной степени определившим устойчивый рост научного интереса к проблемам внутри региональной миграции и формирование современных исследовательских схем, стала муниципальная реформа. Смещение центра тяжести в реализации социально-экономической политики на муниципальный уровень обнаружило недостаточную теоретическую проработанность вопросов анализа внутри региональной миграции, отсутствие адекватных методик оценки ее направлений, масштабов и последствий, стало стимулом для 
проведения новых исследований. Этому способствовало и изменение приоритетов в мировой демографической науке, в которой наблюдаются разукрупнение объекта исследований и уверенный рост интереса к анализу территорий с малой численностью населения - так называемым малым территориям ("small area”).

В 2010-е гг. издано значительное число работ о региональных особенностях миграции в Российской Федерации с включением муниципального блока (Вакуленко, 2012; Кретова, Попкова, 2014; Мкртчян, 2015; Мотрич, Молодковец, 2015). Работы, непосредственно посвященные миграционному обмену между муниципальными образованиями субъектов Российской Федерации, крайне малочисленны, но весьма интересны и разнообразны по методике анализа. Представляют значительный интерес попытки моделирования миграционных потоков на уровне муниципальных образований регионов России (Вакуленко, 2011), опыт применения используемой в социально-экономической географии гравитационной модели для анализа внутриобластных миграций на примере (Василенко, 2013), методика оценки межмуниципальных миграционных связей, включающая оценку их интенсивности и результативности (Стешина, 2010), ретроспективный анализ внутри региональной миграции населения (Верещагин, 2015), исследование гендерных особенностей внутри региональной миграции (Леонидова, Вячеславов, 2016).

Особую группу представляют работы, направленные на оценку различных аспектов влияния миграции на социально-экономическое развитие муниципальных образований, а также использование показателей межмуниципальной миграции в комплексном анализе экономического развития территории (Карачурина, Мкртчян, 2016;Симарова, 2014). Значительный вклад в социологический анализ миграционного поведения населения Алтайского края, изучение причинно-фракторных механизмов миграции населения внесли исследователи Алтайского государственного университета (Сергиенко, Иванова, 2016; Родионова, 2017; Гончарова, 2017).

Таким образом, за период становления отечественной миграционной школы был накоплен значительный теоретический и методический опыт, разработана система показателей миграции и методов их анализа, которые могут быть использованы для оценки внутри региональных миграций в Алтайском крае и других регионах страны.

Результаты. Алтайский край относится к территориям Российской Федерации, численность которых сокращается вследствие естественной убыли и миграционного оттока. В 2016 году таких регионов насчитывалось 23, в 2017 году их количество увеличилось до 38 (Численность и миграция, 2018). Миграция имеет значительное влияние на динамику численности населения региона. С 2001 г. миграционное сальдо Алтайского края приняло отрицательные значения, что на фоне естественной убыли способствовало сокращению общей численности населения. Миграционная убыль в межрегиональных потоках заметно превышает миграционный прирост за счет стран СНГ; его масштабы в 2015-2017 гг. снизились, что обусловлено частичным исчерпанием миграционного потенциала сопредельных территорий.

Анализ удельного веса отдельных направлений миграции показал, что доля внутрирегиональной миграции снизилась в 2011-2017 гг. с 67,7\% до 52,9\%; при этом доля внешней для края миграции, то есть межрегиональной и международной, поступательно увеличивалась. В изучаемый период доля межрегиональной миграции возросла с $26,7 \%$ до $34,6 \%$, международной — с 
5,6\% до 12,5\% (Миграционные процессы, 2017: 14; Миграция населения, 2018 : $6)$.

Алтайский край отличается относительно сбалансированной по возрасту структурой миграционных потоков. Различные возрастные группы населения имеют неодинаковую степень миграционной мобильности и в зависимости от возраста и мотивации включены в разные типы миграционных потоков. Наибольшая миграционная активность свойственна лицам трудоспособного возраста. Они составляют около 73\% как среди прибывших, так и выбывших, при том что доля данной возрастной группы в составе постоянного населения региона - 54,5\% (Демографический ежегодник 2017: 24). Граждане моложе трудоспособного возраста (0-15 лет), как правило, участвуют в миграции не самостоятельно, а вместе со своими семьями, поэтому их доля в числе мигрантов ниже, чем в структуре постоянного населения региона $(18,9 \%$ на 1 января 2017 г.). Лица старше трудоспособного возраста образуют $26,6 \%$ населения региона, а среди мигрантов - чуть более 10\%. Особенностями миграции пожилых являются ориентация на территории проживания родственников (детей, внуков), семейный характер миграции, что заметно отличается от миграции молодежи (Тарасова, 2013).

Возрастными особенностями пространственной мобильности обусловлены последствия миграции для структуры населения Алтайского края. Наибольшую миграционную убыль имеет трудоспособное население, активно включенное в учебные и трудовые миграции в пределах Российской Федерации. Некоторое время край имел положительные значения миграционного прироста по населению старше трудоспособного возраста, но в 2015-2017 гг. и по данному возрастному контингенту возникла миграционная убыль.

Муниципальные образования Алтайского края имеют неоднородные результаты миграционных процессов, что обусловлено множеством факторов: географическим положением, составом населения, развитостью инфраструктуры, текущей социально-экономической ситуацией и связанной с ней динамикой индивидуальных потребностей.

Среди территорий Алтайского края максимальные значения коэффрициента миграционного оборота, свидетельствующие о высокой степени включенности населения в миграционные процессы, в 2017 г. имели Алейский район, г. Алейск, Бурлинский, Егорьевский, Рубцовский районы. Минимальные значения данного показателя и, соответственно, невысокая миграционная мобильность населения зафиксированы в Волчихинском, Каменском, Хабарском, УстьКалманском и Тюменцевском районах.

Максимальные показатели коэфффициента интенсивности миграции по прибытию зафиксированы в г. Алейске, Алейском, Бурлинском, Первомайском, Ельцовском районах. Минимальные значения данного коэффициента наблюдались в Волчихинском, Курьинском, Каменском, Хабарском, Третьяковском районах.

Наивысшие значения коэффрициента интенсивности миграции по выбытию в 2017 г. отмечены в Алейском, Угловском, Рубцовском районах, г. Алейске, Бурлинском районе. Наименьших значений этот коэфффициент достиг в УстьКалманском районе, г. Новоалтайске, Каменском, Поспелихинском и Волчихинском районах.

Необходимо отметить, что выгоды и потери от миграции неравномерно распределяются между городским и сельским населением края. Городские поселения имели больший (хоть и сокращающийся) по сравнению с сельскими территориями миграционный прирост в международной миграции, 
неустойчивый баланс во внутрироссийской миграции, и в рассматриваемый период лишь в 2015-2017 гг. столкнулись с общей миграционной убылью. Прирост городов в миграционном обмене с сельскими поселениями в 2017 г. увеличился вдвое в сравнении с 2016 г. и составил 2042 чел.

Масштабы прироста сельских поселений в международной миграции постепенно сокращались, в результате в 2017 г. он принял отрицательное значение. Однако и размеры миграционной убыли сельского населения Алтайского края во внутрироссийском обмене снижались быстрыми темпами. Миграционная убыль по данному направлению снизилась с -11364 чел. в 2012 г. до -3698 чел. в 2016 г. (в 3,1 раза), однако в 2017 г. снова увеличилась на 46,8 \% в сравнении с предшествующим годом.

Поскольку прирост населения муниципального образования складывается как результат внутри краевой, межрегиональной и международной миграции, сходные показатели миграционного прироста могут быть следствием различных сочетаний показателей трех направлений миграции. По итогам внутри краевой и международной миграции, муниципальные образования Алтайского края имеют и положительные, и отрицательные значения миграционного прироста, в то время как в межрегиональных перемещениях большинство территорий несет значительные миграционные потери.

С целью типологического анализа демографрического развития Федеральная служба государственной статистики делит территории на шесть групп на основе показателей естественного и миграционного прироста и характера изменения численности населения (Численность и миграция, 2018). Применение типологического подхода к анализу особенностей демографического развития муниципальных образований имеет и научную, и управленческую ценность благодаря возможности рассмотрения вклада отдельных территорий в изменение демографического портрета региона, пространственные особенности и долгосрочные тенденции развития народонаселения. По аналогии может быть предложена типология территорий в зависимости от значений и компонентов миграционного прироста (см. Таблица 1).

\begin{tabular}{|c|c|c|}
\hline $\begin{array}{l}\text { Сочетание компонентов } \\
\text { миграционного прироста }\end{array}$ & $\begin{array}{l}\text { Число } \\
\text { территорий } \\
\text { в группе }\end{array}$ & $\begin{array}{l}\text { Перечень } \\
\text { муниципальных } \\
\text { образований }\end{array}$ \\
\hline \multicolumn{3}{|c|}{ Территории с положительными значениями миграционного прироста } \\
\hline $\begin{array}{lrr}\text { Миграционный } & \text { прирост за счет всех } \\
\text { направлений } & \text { миграции (внутри } \\
\text { региональная, } & \text { межрегиональная, } \\
\text { международная) } & \\
\end{array}$ & 2 & $\begin{array}{l}\text { Крутихинский, Петропавловский } \\
\text { районы }\end{array}$ \\
\hline $\begin{array}{l}\text { Превышение прироста во внутри } \\
\text { региональной и межрегиональной } \\
\text { миграции над убылью } \\
\text { международном обмене }\end{array}$ & 0 & \\
\hline $\begin{array}{l}\text { Превышение прироста во внутри } \\
\text { региональном обмене над убылью в } \\
\text { межрегиональной и международной } \\
\text { миграции }\end{array}$ & 1 & Первомайский район \\
\hline $\begin{array}{l}\text { Превышение прироста во внутри } \\
\text { региональном и международном } \\
\text { обмене над убылью } \\
\text { межрегиональной миграции }\end{array}$ & 9 & $\begin{array}{lr}\text { г. } \quad \text { Алейск, } & \text { г. } \begin{array}{r}\text { Яровое, } \\
\text { Залесовский, }\end{array} \\
\text { Кулундинский, } & \text { Мамальный, } \\
\text { Поспелихинский, } & \text { Тальменский, } \\
\text { Шелаболихинский районы }\end{array}$ \\
\hline Превышение & 1 & Ельцовский район \\
\hline
\end{tabular}




\begin{tabular}{|c|c|c|}
\hline $\begin{array}{l}\text { Сочетание компонентов } \\
\text { миграционного прироста }\end{array}$ & $\begin{array}{l}\text { Число } \\
\text { территорий } \\
\text { в группе } \\
\end{array}$ & $\begin{array}{l}\text { Перечень } \\
\text { муниципальных } \\
\text { образований } \\
\end{array}$ \\
\hline \multicolumn{3}{|l|}{$\begin{array}{l}\text { межрегиональном и международном } \\
\text { обмене над убылью во внутри } \\
\text { региональной миграции }\end{array}$} \\
\hline $\begin{array}{llr}\text { Превышение } & \text { прироста } & \text { в } \\
\text { межрегиональном } & \text { обмене } \text { над } \\
\text { убылью во внутри региональной и } \\
\text { международной миграции }\end{array}$ & 0 & \\
\hline $\begin{array}{llr}\text { Превышение } & \text { прироста } & \text { в } \\
\text { международном обмене над убылью } \\
\text { во внутри региональной } \\
\text { межрегиональной миграции }\end{array}$ & 0 & \\
\hline \multicolumn{3}{|c|}{$\begin{array}{l}\text { Территории с отрицательными значениями } \\
\text { миграционного прироста (убылью) }\end{array}$} \\
\hline $\begin{array}{l}\text { Миграционная убыль за счет всех } \\
\text { направлений } \\
\text { (внутрирегиональная, } \\
\text { межрегиональная, международная) }\end{array}$ & 21 & $\begin{array}{lr}\text { Г. Белокуриха, } & \text { Г. Славгород, } \\
\text { Бийский, } & \text { Завьяловский, } \\
\text { Калманский, } & \text { Ключевский, } \\
\text { Косихинский, } & \text { Краснощековский, } \\
\text { Курьинский, } & \text { Локтевский, } \\
\text { Немецкий } & \text { национальный, } \\
\text { Павловский, } & \text { Панкрушихинский, } \\
\text { Смоленский, } & \text { Советский, } \\
\text { Солтонский, } & \text { Суетский, } \\
\text { Табунский, } & \text { Угловский, Усть- } \\
\text { Пристанский, Чарышский районы }\end{array}$ \\
\hline $\begin{array}{lr}\text { Превышение миграционной убыли во } \\
\text { внутрирегиональной } & \text { и } \\
\text { межрегиональной } \quad \text { миграции } \\
\text { миграционным над } \\
\text { международном обмене }\end{array}$ & 17 & $\begin{array}{lr}\text { Алтайский, } & \text { Баевский, } \\
\text { Волчихинский, } & \text { Егорьевский, } \\
\text { Заринский, } & \text { Змеиногорский, } \\
\text { Каменский, } & \text { Кытмановский, } \\
\text { Родинский, } & \text { Романовский, } \\
\text { Рубцовский, } & \text { Солонешенский, } \\
\text { Третьяковский, } & \text { Троицкий, } \\
\text { Тюменцевский, } & \text { Хабарский, } \\
\text { Шипуновский районы }\end{array}$ \\
\hline $\begin{array}{l}\text { Превышение миграционной убыли во } \\
\text { внутри краевой миграции над } \\
\text { миграционным приростом п } \\
\text { межрегиональном и международном } \\
\text { обмене }\end{array}$ & 3 & $\begin{array}{l}\text { Бурлинский, Быстроистокский, } \\
\text { Красногорский районы }\end{array}$ \\
\hline $\begin{array}{lrr}\text { Превышение миграционной убыли во } \\
\text { внутри региональной } \\
\text { международной } \quad \text { миграции } \\
\text { миграционным над } \\
\text { межрегиональном обмене }\end{array}$ & 0 & \\
\hline 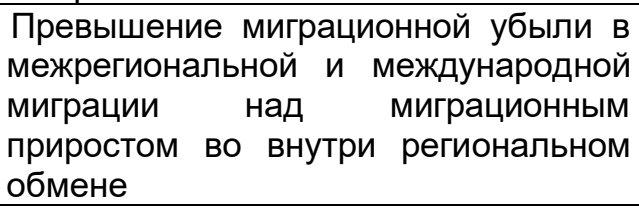 & 3 & $\begin{array}{l}\text { г. Бийск, Благовещенский, } \\
\text { Тогульский районы }\end{array}$ \\
\hline $\begin{array}{l}\text { Превышение миграционной убыли в } \\
\text { международном обмене над } \\
\text { приростом во внутри региональной и } \\
\text { межрегиональной миграции }\end{array}$ & 0 & \\
\hline Превышение & 12 & Барнаул, \\
\hline
\end{tabular}




\begin{tabular}{|l|l|l|}
\hline $\begin{array}{l}\text { Сочетание компонентов } \\
\text { миграционного прироста }\end{array}$ & $\begin{array}{l}\text { Число } \\
\text { территорий } \\
\text { в группе }\end{array}$ & $\begin{array}{l}\text { Перечень } \\
\text { муниципальных } \\
\text { образований }\end{array}$ \\
\hline $\begin{array}{l}\text { межрегиональном обмене над } \\
\text { приростом во внутри региональной и } \\
\text { международной миграции }\end{array}$ & $\begin{array}{l}\text { Новоалтайск, г. Рубцовск, 3АТО } \\
\text { Сибирский, } \\
\text { Михайловский, Новичихинский, } \\
\end{array}$ & $\begin{array}{l}\text { Ребрихинский, Топчихинский, } \\
\text { Усть-Калманский, Целинный } \\
\text { районы }\end{array}$ \\
\hline
\end{tabular}

Таблица 1. Типология территорий Алтайского края по показателям миграции в 2017 г.

По итогам внутри краевой и международной миграции муниципальные образования региона имеют как положительные, так и отрицательные значения миграционного прироста, в то время как в межрегиональных перемещениях большинство территорий несет значительные миграционные потери.

По итогам 2017 г. лишь 13 территорий Алтайского края из 69 имели миграционный прирост (в 2016 г. - 21 муниципальное образование). Максимальные положительные значения коэффициента миграционного прироста имели Крутихинский, Первомайский районы, г. Алейск, Ельцовский и Петропавловский районы. Максимальные отрицательные значения зафиксированы в Третьяковском, Угловском, Курьинском, Немецком национальном, Бийском районах.

Наиболее многочисленной является группа территорий, для которой характерны отрицательные значения миграционного прироста за счет превышения убыли во внутри региональной и межрегиональной миграции над приростом в международном обмене. В нее вошло 21 муниципальное образование Алтайского края (в 2015 г. таких территорий насчитывалось 6, в 2016 г. - 7). На втором месте по численности - территории, которым свойственно превышение миграционной убыли во внутри региональной и межрегиональной миграции над миграционным приростом в международном обмене. В 2017 г. их начитывалось 17, в то время как в 2015 г. - 36, в 2016 г. 26. Столь существенные изменения происходят прежде всего в связи с исчерпанием компенсационного потенциала международной миграции.

Необходимо отметить, что многие муниципальные образования края отличаются неустойчивым типом миграционной ситуации, поэтому в ближайшие годы могут перейти в другие группы территорий. Эта тенденция определяет нестабильную динамику показателей миграции в регионе в целом, требуя дополнительных усилий по организации мониторинга, прогнозирования и разработки моделей воздействия на пространственную мобильность населения.

Муниципальные образования Алтайского края в значительной степени дифференцированы по доле внутри краевой миграции в структуре прибытия и выбытия. Для анализа направлений и интенсивности миграционных связей между муниципальными образованиями использованы данные Управления Федеральной службы государственной статистики по Алтайскому краю и Республике Алтай, отражающие внутри региональную миграцию населения по территориям прибытия и выбытия за 2014-2016 гг. (данные за другие годы были недоступны для анализа в период проведения исследования). С целью выявления наиболее тесных связей между территориями Алтайского края использовались значения коэфффициента интенсивности миграционных связей 
(далее - КИМС), рассчитанные по прибытию и выбытию для каждого муниципального района и городского округа.

При сравнении значений КИМС за отдельные годы отмечается преимущественная стабильность межмуниципальных миграционных связей и по прибытиям, и по выбытиям.

Поскольку муниципальные образования региона относятся к малым территориям, и отдельные муниципалитеты зачастую имеют невысокие количественные показатели прибытия и выбытия, то в целях определения наиболее устойчивых направлений межмуниципальной миграции КИМС были рассчитаны на основе показателей прибытия и выбытия, интегрированных за три года (2014-2016 гг.). На основании полученных данных для каждого муниципального образования были выделены три муниципальных района или городских округа, с которыми у него зафиксированы наибольшие по сравнению с другими муниципалитетами значения КИМС по прибытию и по выбытию.

Направления наиболее интенсивных миграционных потоков, определенных на основе значений КИМС по прибытию и по выбытию за 2014-2016 гг., в большинстве случаев совпадают (см. Таблица 2). Исключение составили только три муниципальных района (Калманский, Советский и Солтонский), где наблюдается несовпадение наиболее значимых миграционных потоков по прибытию и выбытию.

По большей части, наиболее интенсивные миграционные связи характерны для соседних муниципалитетов («соседские миграции»). Располагая сведениями о составе населения таких муниципальных образований, как Немецкий национальный район, город Яровое, город Славгород, Бурлинский район, можно предположить, что миграционные связи между ними определяются не только их соседским положением, но и этническим фактором.

\begin{tabular}{|c|c|c|}
\hline $\begin{array}{l}\text { № } \\
\text { п/п }\end{array}$ & $\begin{array}{l}\text { Наименование } \\
\text { муниципального образования }\end{array}$ & Основные миграционные партнеры \\
\hline 1 & Алейский район & город Алейск \\
\hline 2 & Алтайский район & $\begin{array}{l}\text { город Белокуриха, Советский м } \\
\text { район }\end{array}$ \\
\hline 3 & Баевский район & Суетский район \\
\hline 4 & Бийский район & город Бийск, Красногорский район \\
\hline 5 & Благовещенский район & Суетский район, Родинский район \\
\hline 6 & Бурлинский район & Табунский район \\
\hline 7 & Быстроистокский район & $\begin{array}{l}\text { Смоленский } \\
\text { Петропавловский район }\end{array}$ \\
\hline 8 & Волчихинский район & Родинский район \\
\hline 9 & Егорьевский район & $\begin{array}{l}\text { Новичихинский район, город } \\
\text { Рубцовск }\end{array}$ \\
\hline 10 & Ельцовский район & Тогульский район \\
\hline 11 & Завьяловский район & Романовский район, Баевский район \\
\hline 12 & Залесовский район & $\begin{array}{l}\text { Кытмановский } \\
\text { Шелаболихинский район }\end{array}$ \\
\hline 13 & Заринский район & $\begin{array}{l}\text { город Заринск, Кытмановский район, } \\
\text { Залесовский район }\end{array}$ \\
\hline 14 & Змеиногорский район & $\begin{array}{l}\text { Третьяковский район, Локтевский } \\
\text { район }\end{array}$ \\
\hline 15 & Каменский район & $\begin{array}{l}\text { Баевский район, город Камень-на- } \\
\text { Оби, Крутихинский район }\end{array}$ \\
\hline 16 & Ключевский район & $\begin{array}{l}\text { Михайловский район, Кулундинский } \\
\text { район }\end{array}$ \\
\hline
\end{tabular}




\begin{tabular}{|c|c|c|}
\hline $\begin{array}{l}\text { № } \\
\text { ח/ח }\end{array}$ & $\begin{array}{l}\text { Наименование } \\
\text { муниципального образования }\end{array}$ & Основные миграционные партнеры \\
\hline 17 & Косихинский район & Сибирский городской округ (ЗАТО) \\
\hline 18 & Красногорский район & Бийский район \\
\hline 19 & Краснощековский район & Чарышский район \\
\hline 20 & Крутихинский район & $\begin{array}{l}\text { Панкрушихинский район, Каменский } \\
\text { район, город Камень-на-Оби }\end{array}$ \\
\hline 21 & Кулундинский район & $\begin{array}{l}\text { Табунский район, Ключевский район, } \\
\text { город Славгород }\end{array}$ \\
\hline 22 & Курьинский район & Краснощековский район \\
\hline 23 & Кытмановский район & $\begin{array}{l}\text { Тогульский район, Заринский район, } \\
\text { город Заринск }\end{array}$ \\
\hline 24 & Локтевский район & $\begin{array}{l}\text { Змеиногорский район, Рубцовский } \\
\text { район }\end{array}$ \\
\hline 25 & Мамонтовский район & $\begin{array}{l}\text { Тюменцевский район, Ребрихинский } \\
\text { район }\end{array}$ \\
\hline 26 & Михайловский район & Ключевский район, Угловский район \\
\hline 27 & Новичихинский район & $\begin{array}{l}\text { Егорьевский район, Поспелихинский } \\
\text { район }\end{array}$ \\
\hline 28 & Зональный район & город Бийск, Троицкий район \\
\hline 29 & Павловский район & $\begin{array}{ll}\text { Шелаболихинский } & \text { район, } \\
\text { Ребрихинский район } & \end{array}$ \\
\hline 30 & Панкрушихинский район & Крутихинский район \\
\hline 31 & Первомайский район & $\begin{array}{l}\text { город Новоалтайск, } \\
\text { городской округ (ЗАТО) }\end{array}$ \\
\hline 32 & Петропавловский район & $\begin{array}{l}\text { Солонешенский район, Чарышский } \\
\text { район }\end{array}$ \\
\hline 33 & Поспелихинский район & Новичихинский район \\
\hline 34 & Ребрихинский район & $\begin{array}{l}\text { Мамонтовский } \\
\text { Шелаболихинский район }\end{array}$ \\
\hline 35 & Родинский район & Благовещенский район \\
\hline 36 & Романовский район & Завьяловский район \\
\hline 37 & Рубцовский район & $\begin{array}{l}\text { Егорьевский район, город Рубцовск, } \\
\text { Угловский район }\end{array}$ \\
\hline 38 & Смоленский район & $\begin{array}{l}\text { Солонешенский район, город } \\
\text { Белокуриха, Быстроистокский район }\end{array}$ \\
\hline 39 & Суетский район & $\begin{array}{l}\text { Баевский район, Благовещенский } \\
\text { район }\end{array}$ \\
\hline 40 & Солонешенский район & $\begin{array}{l}\text { Петропавловский } \\
\text { Смоленский район }\end{array}$ \\
\hline 41 & Шелаболихинский район & Павловский район \\
\hline 42 & Табунский район & Кулундинский район \\
\hline 43 & Тальменский район & $\begin{array}{l}\text { Первомайский район, } \\
\text { городской округ (ЗАТО) }\end{array}$ \\
\hline 44 & Тогульский район & $\begin{array}{l}\text { Ельцовский район, Кытмановский } \\
\text { район, Целинный район }\end{array}$ \\
\hline 45 & Топчихинский район & Алейский район \\
\hline 46 & Третьяковский район & $\begin{array}{l}\text { Змеиногорский район, Локтевский } \\
\text { район }\end{array}$ \\
\hline 47 & Троицкий район & Зональный район \\
\hline 48 & Тюменцевский район & $\begin{array}{l}\text { Мамонтовский } \\
\text { Шелаболихинский район }\end{array}$ \\
\hline 49 & Угловский район & город Рубцовск \\
\hline 50 & Усть-Калманский район & Чарышский район \\
\hline 51 & Усть-Пристанский район & Петропавловский район, Алейский \\
\hline
\end{tabular}




\begin{tabular}{|c|c|c|}
\hline $\begin{array}{l}\text { № } \\
\text { ח/ח }\end{array}$ & $\begin{array}{l}\text { Наименование } \\
\text { муниципального образования }\end{array}$ & Основные миграционные партнеры \\
\hline & & район \\
\hline 52 & Хабарский район & $\begin{array}{l}\text { Суетский район, } \\
\text { национальный район }\end{array}$ \\
\hline 53 & Целинный район & Ельцовский район, Тогульский район \\
\hline 54 & Чарышский район & $\begin{array}{l}\text { Петропавловский } \\
\text { Калманский район }\end{array}$ район, \\
\hline 55 & Шипуновский район & Алейский район \\
\hline 56 & Немецкий национальный район & Табунский район \\
\hline 57 & город Барнаул & Топчихинский район \\
\hline 58 & город Алейск & Алейский район \\
\hline 59 & город Белокуриха & Алтайский район, Смоленский район \\
\hline 60 & город Бийск & Бийский район \\
\hline 61 & город Заринск & $\begin{array}{l}\text { Заринский район, Кытмановский } \\
\text { район, }\end{array}$ \\
\hline 62 & город Камень-на-Оби & $\begin{array}{l}\text { Каменский район, Крутихинский } \\
\text { район }\end{array}$ \\
\hline 63 & город Новоалтайск & $\begin{array}{l}\text { Первомайский район, } \\
\text { городской округ (ЗАТО) }\end{array}$ \\
\hline 64 & город Рубцовск & $\begin{array}{l}\text { Рубцовский район, Егорьевский } \\
\text { район, Угловский район }\end{array}$ \\
\hline 65 & город Славгород & Бурлинский район, Табунский район \\
\hline 66 & город Яровое & город Славгород, Бурлинский район \\
\hline 67 & Сибирский городской округ (ЗАТО) & $\begin{array}{l}\text { Первомайский район, Косихинский } \\
\text { район }\end{array}$ \\
\hline
\end{tabular}

Таблица 2. Территории, характеризующиеся совпадением наиболее интенсивных миграционных потоков по прибытию и выбытию в 2014-2016 гг.

Лишь в некоторых случаях в число муниципалитетов с наиболее интенсивными миграционными связями, определенными в соответствии со значениями КИМС за 2014-2016 гг. суммарно, попадали муниципальные образования, не отличавшиеся высокой интенсивностью миграционных потоков по однолетним периодам. К территориям такого типа относятся следующие муниципалитеты:

- Зональный район, куда довольно активно выбывают мигранты из Алтайского района,

- Кулундинский район, откуда приезжают в Благовещенский район,

- Сибирский городской округ (ЗАТО), куда выбывают из Бурлинского района,

- Новичихинский район, откуда прибывают в Волчихинский район,

- Родинский район, куда выбывают из Калманского и Романовского районов,

- Солтонский район, откуда прибывают в Краснощековский район,

- Панкрушихинский район, откуда прибывают в Крутихинский район,

- город Рубцовск, куда выбывают из Новичихинского района,

- Бийский район, откуда прибывают в Зональный район,

- Ключевский район, откуда прибывают в Усть-Пристанский район,

- Быстроистокский район, куда выбывают из города Белокуриха,

- город Новоалтайск, куда выбывают из города Заринска,

- город Алейск, откуда прибывают в Сибирский городской округ (ЗАТО).

Оценка количества территорий, с которыми у отдельных муниципальных образований отмечаются наиболее интенсивные внутри региональные 
миграционные связи, позволяет выявить степень их «симметричности». По каждому муниципальному образованию были выделены территории, для которых оно в 2014-2016 гг. входило в тройку ведущих районов выхода и вселения (то есть основных миграционных партнеров) на основе значений КИМС по прибытию и выбытию, и подсчитано их общее количество. На основе полученных данных можно сделать вывод, что самым большим количеством миграционных партнеров с высокими показателями интенсивности связей отличается Егорьевский район. Он притягивает мигрантов из 12 других муниципальных образований Алтайского края. Помимо этого, высокие значения КИМС по выбытию в Петропавловский район и город Бийск имеют 8 муниципалитетов, в Сибирский городской округ - 7 муниципалитетов, в Алейский район и город Рубцовск - 6 муниципалитетов. Баевский, Солонешенский, Угловский районы стоят в первом ряду среди территорий выхода мигрантов для 7 муниципалитетов Алтайского края. Большие значения КИМС по прибытию из Суетского, Солтонского, Табунского районов имеют 6 территорий. Алейский, Быстроистокский, Косихинский, Шелаболихинский, Чарышский, Немецкий национальный районы наиболее интенсивно теряют население в пользу 5 муниципальных образований. В Бурлинском, Краснощековском, Кытмановском, Новичихинском, Петропавловском, Тогульском, Усть-Пристанском районах и Сибирском городском округе (ЗАТО) наблюдается значительный отток населения в 4 муниципалитета.

Следует отметить, что согласно значениям КИМС, город Барнаул и Шипуновский район не выступали в качестве основных территорий выхода и/или вселения для других муниципалитетов. Тальменский район и город Яровое не принадлежат к числу основных доноров в межмуниципальной миграции. Курьинский, Усть-Пристанский, Хабарский районы не являются основными территориями вселения, принимающими мигрантов из других муниципальных районов и городских округов Алтайского края.

С позиции соотношения выполняемых муниципалитетами ролей, 29 из них чаще являлись территориями, принимающими мигрантов. Такое же количество муниципалитетов в большинстве случаев интенсивно отдавало свое население в миграционном обмене. 10 муниципальных образований стали основными районами как вселения, так и выхода мигрантов для одинакового количества муниципалитетов.

Заключение. Таким образом, анализ интенсивности межмуниципальных миграционных связей показал, что для всех территорий Алтайского края характерны преимущественно «соседские» миграции. Однако, они «несимметричны»: у большинства муниципальных образований число территорий выхода мигрантов и территорий вселения во внутри краевом обмене неодинаково. Более того, для ряда территорий перечень основных миграционных партнеров по показателям КИМС совпадает лишь частично.

Межмуниципальная миграция существенно влияет на численность и возрастно-половую структуру населения территорий, обостряя их демографическое неравенство. Неравенство демографических потенциалов выступает, с одной стороны, как последствие неоднородности экономикогеографических условий развития локальных социумов, с другой стороны - как фактор, создающий предпосылки для экономического роста либо ограничивающий его возможности. Анализ характера и устойчивости связей между внутрирегиональной миграцией и показателями социальноэкономического развития муниципальных образований имеет большую научную и практическую значимость, поскольку обусловленные 
межмуниципальной миграцией изменения численности, структуры и размещения населения способны существенно повлиять на темпы экономического роста территории, условия реализации долгосрочных проектов и программ, финансовую обеспеченность муниципалитетов.

Благодарности. Работа подготовлена при поддержке РФФИ, проект № 1713-22007 a(p) «Миграция сельской молодежи в Алтайском крае: анализ динамики и механизмов сокращения на основе комплексного измерения социального положения и активности»

\section{Әдебиеттер тізімі/ Список литературы}

1. Василенко П.В. Применение гравитационной модели для анализа внутриобластных миграций на примере Новгородской и Псковской областей // Псковский регионологический журнал. 2013. № 15. С.83-90.

2. Вакуленко Е.С. Миграционные процессы в городах Центральной России и Сибири // XIII Международная научная конференция по проблемам развития экономики и общества. В 4 кн. Кн. 3. / Отв. ред.: Е.Г. Ясин. Кн. 3.М.: Издательский дом НИУ ВШЭ, 2012. С. 103-112.

3. Вакуленко Е.С., Мкртчян Н.В., Фурманов К. К. Опыт моделирования миграционных потоков на уровне регионов и муниципальных образований РФ // Научные труды: Институт народнохозяйственного прогнозирования РАН. 2011. № 1. С. 431-450.

4. Верещагин, И.Ф. Долговременные факторы внутрирегиональной миграции на территории Архангельской области в XX веке // Вестн. Север. (Аркт.) федерал. ун-та. Сер. Гуманитарные и социальные науки. 2015. №1. С. 5-14.

5. Гончарова, Н. П. Социологическое сопровождение мониторинга демографических процессов в Алтайском крае // Проблемы методологии и методики мониторинга социальноэкономического развития регионов Российской Федерации. Саранск, 2017. С. 122-127.

6. Демографический ежегодник Алтайского края : стат. сб. Барнаул, 2017.

7. Зайончковская Ж.А. Новоселы в городах. М. : Статистика, 1972.

8. Зайончковская Ж.А. Современная миграция населения Красноярского края/ Зайончковская Ж. А., Переведенцев В.И. Новосибирск, 1964; Зайончковская, Ж. А. Новоселы в городах [Текст]. М. : Статистика, 1972.

9. Карачурина Л.Б., Мкртчян Н.В. Роль миграции в усилении контрастов расселения на муниципальном уровне в России // Известия Российской академии наук. Серия географическая. 2016. № 5. C. 46-59.

10. Кретова О.Г. Территориальная дифференциация миграционной подвижности населения Курской области] / Кретова О.Г., Попкова Л.И. // Вестн. Воронеж. гос. ун-та. Сер. География. Геоэкология. 2014. №2. С. 8-16.

11. Леонидова Г.В. Гендерные особенности внутри региональной миграции / Леонидова Г. В., Вячеславов В.Н.// Вопр. территориального развития. 2016. №2 (32). С. 1-12.

12. Миграционные процессы в Алтайском крае 2011-2016 : стат. сб. Барнаул, 2017.

13. Миграция населения Алтайского края в 2017 году: Стат. бюл./ Управление Федеральной службы государственной статистики по Алтайскому краю и Республике Алтай. - Барнаул, 2018.

14. Мкртчян Н.В. Миграция в Москве и Московской области: региональные и структурные особенности // Региональные исследования. 2015. № 3. С. 107-116.

15. Мкртчян Н.В. Миграция молодежи из малых городов России // Мониторинг общественного мнения: экономические и социальные перемены. 2017. С. 225-242.

16. Мкртчян Н.В. Пространственные особенности внутрироссийской миграции в постсоветский период // Современные исследования миграции населения. М.: Экономический факультет МГУ им. М.В. Ломоносова, 2015. С.94-111.

17. Мотрич Е.Л., Молодковец Л.А. Трансформация миграционных процессов в Хабаровском крае // Вопросы статистики. 2015. № 1. С. 54-64.

18. Переведенцев, В. И. Современная миграция населения Западной Сибири. Новосибирск : Зап.-Сиб. кн. изд-во, 1965.

19. Родионова Л.В. Миграция как фактор и барьер социально-экономической модернизации в агропромышленном регионе // Островские чтения. 2017. №1. С. 521-529.

20. Рыбаковский Л.Л. Проблемы формирования народонаселения Дальнего Востока / Акад. наук СССР, Сиб. отд-ние. Хабаровск, 1969.

21. Сергиенко А.М. Миграция сельской молодежи как индикатор благополучия села / Сергиенко А.М., Иванова О.А. // Социология в современном мире: наука, образование, творчество. 2016. №8-2. C. 21-26. 
22. Симарова И.С. Миграционный обмен как фрактор внутрирегиональной связанности // Теория и практика общественного развития. 2014. №3. С.298-301.

23. Стешина М.П. Методика оценки межмуниципальных миграционных связей // Вестн. Самар. гос. экон. ун-та. 2010. №6 (68). С. 76-80.

24. Тарасова Е.В. Особенности миграции населения старше трудоспособного возраста в Алтайском крае // Социальная интеграция и развитие этнокультур в евразийском пространстве. Барнаул, 2013. С. 153.

25. Тарасова Е.В., Ерохин А.В., Сбитнева Н.А. Внутрирегиональная миграция в Алтайском крае. Барнаул: ИП Колмогоров И.А., 2015.

26. Численность и миграция населения Российской Федерации в 2017 году [Электронный ресурс] : (стат. бюл.). - Электрон. дан. - Режим доступа: http://www.gks.ru/bgd/regl/b18_107/Main.htm.

\section{References}

Vasilenko 2013 - Vasilenko, PV 2013 Primenenie gravitacionnoj modeli dlja analiza vnutrioblastnyh migracij na primere Novgorodskoj i Pskovskoj oblastej // Pskovskij regionologicheskij zhurnal. № 15. S.83-90. (in Rus).

Vakulenko 2012 - Vakulenko, ES 2012 MigracionnyeprocessyvgorodahCentral'nojRossiiiSibiri // XIIIMezhdunarodnajanauchnajakonferencijapoproblemamrazvitijajekonomikiiobshhestva. V 4 kn. Kn. 3. / Otv. red.: E. G. Jasin. Kn. 3. M.: Izdatel'skij dom NIU VShJe. S. 103-112. (in Rus).

Vakulenko 2011 - Vakulenko, ES, Mkrtchjan, NV, Furmanov, KK 2011 Opyt modelirovanija migracionnyh potokov na urovne regionov i municipal'nyh obrazovanij RF // Nauchnye trudy: Institut narodnohozjajstvennogo prognozirovanija RAN. № 1. S. 431-450.(in Rus).

Vereshhagin 2015 - Vereshhagin, IF 2015 Dolgovremennye faktory vnutriregional'noj migracii na territorii Arhangel'skoj oblasti v XX veke // Vestn. Sever. (Arkt.) federal. un-ta. Ser. Gumanitarnye i social'nye nauki. №1. S. 5-14. (in Rus).

Goncharova 2017 - Goncharova, NP 2017 Sociologicheskoe soprovozhdenie monitoringa demograficheskih processov v Altajskom krae // Problemy metodologii i metodiki monitoringa social'no-jekonomicheskogo razvitija regionov Rossijskoj Federacii. Saransk. S. 122-127.(in Rus).

Demograficheskij ezhegodnik 2017 - Demograficheskij ezhegodnik Altajskogo kraja : stat. sb. Barnaul, 2017.(in Rus).

Zajonchkovskaja 1972 - Zajonchkovskaja, ZhA 1972 Novosely v gorodah. M. : Statistika. (in Rus).

Zajonchkovskaja 1964 - Zajonchkovskaja, ZhA 1972 Sovremennaja migracija naselenija Krasnojarskogo kraja/ Zajonchkovskaja Zh. A., Perevedencev V. I. Novosibirsk, 1964; Zajonchkovskaja, Zh. A. Novosely v gorodah M.: Statistika. (in Rus).

Karachurina 2016 - Karachurina, LB, Mkrtchjan, NV 2016 Rol' migracii v usilenii kontrastov rasselenija na municipal'nom urovne v Rossii // Izvestija Rossijskoj akademii nauk. Serija geograficheskaja. № 5. S. 46-59.(in Rus).

Kretova 2014 - Kretova, OG 2014 Territorial'naja differenciacija migracionnoj podvizhnosti naselenija Kurskoj oblasti]. // Vestn. Voronezh. gos. un-ta. Ser. Geografija. Geojekologija. №2. S. 8-16.(in Rus).

Leonidova 2016 - Leonidova, GV 2016 Gendernye osobennosti vnutriregional'noj migracii // Vopr. territorial'nogo razvitija.. №2 (32). S. 1-12.(in Rus).

Migracionnye processy 2017 - Migracionnye processy v Altajskom krae 2011-2016 : stat. sb. Barnaul, 2017.(in Rus).

Migracija naselenija 2018 - Migracija naselenija Altajskogo kraja v 2017 godu: Stat. bjul./ Upravlenie Federal'noj sluzhby gosudarstvennoj statistiki po Altajskomu kraju i Respublike Altaj. - Barnaul, 2018. (in Rus).

Mkrtchjan 2015a - Mkrtchjan, NV 2015 Migracija v Moskve i Moskovskoj oblasti: regional'nye i strukturnye osobennosti // Regional'nye issledovanija. № 3. S. 107-116.(in Rus).

Mkrtchjan 2017 - Mkrtchjan, NV 2017 Migracija molodezhi iz malyh gorodov Rossii // Monitoring obshhestvennogo mnenija: jekonomicheskie i social'nye peremeny. S. 225-242.(in Rus).

Mkrtchjan 2015b - Mkrtchjan, NV 2015 Prostranstvennye osobennosti vnutrirossijskoj migracii v postsovetskij period // Sovremennye issledovanija migracii naselenija. M.: Jekonomicheskij fakul'tet MGU im. M.V. Lomonosova. S.94-111. (in Rus).

Motrich 2015 - Motrich, EL, Molodkovec, LA 2015 Transformacija migracionnyh processov v Habarovskom krae // Voprosy statistiki. № 1. S. 54-64.(in Rus).

Perevedencev 1965 - Perevedencev, VI 1965 Sovremennaja migracija naselenija Zapadnoj Sibiri. Novosibirsk : Zap.-Sib. kn. izd-vo. (in Rus).

Rodionova 2017 - Rodionova, LV 2017 Migracija kak faktor i bar'er social'no-jekonomicheskoj modernizacii v agropromyshlennom regione // Ostrovskie chtenija. №1. S. 521-529.(inRus). 
Rybakovskij 1969 - Rybakovskij, LL 1969 Problemy formirovanija narodonaselenija Dal'nego Vostoka / Akad. nauk SSSR, Sib. otd-nie. Habarovsk. (in Rus).

Sergienko 2016 - Sergienko, AM 2016 Migracija sel'skoj molodezhi kak indikator blagopoluchija sela // Sociologija v sovremennom mire: nauka, obrazovanie, tvorchestvo. №8-2. S. 21-26. (in Rus).

Simarova 2014 - Simarova, IS 2014 Migracionnyj obmen kak faktor vnutriregional'noj svjazannosti // Teorija i praktika obshhestvennogo razvitija. №3. S.298-301. (in Rus).

Steshina 2010 - Steshina, MP 2010 Metodika ocenki mezhmunicipal'nyh migracionnyh svjazej // Vestn. Samar. gos. jekon. un-ta. №6 (68). S. 76-80. (in Rus).

Tarasova 2013 - Tarasova, EV 2013 Osobennosti migracii naselenija starshe trudosposobnogo vozrasta $v$ Altajskom krae // Social'naja integracija i razvitie jetnokul'tur v evrazijskom prostranstve. Barnaul. S. 153. (in Rus).

Tarasova 2015 - Tarasova, EV, Erohin, AV, Sbitneva, NA 2015 Vnutriregional'naja migracija v Altajskom krae. Barnaul: IP Kolmogorov I.A.. (in Rus).

Chislennost' i migracija 2018 - Chislennost' i migracija naselenija Rossijskoj Federacii v 2017 godu [Jelektronnyj resurs] : (stat. bjul.). - Jelektron. dan. - Rezhim dostupa: http://www.gks.ru/bgd/regl/b18 107/Main.htm. (in Rus). 